\title{
ポリアクリルニトリル繊維の熱取縮と非晶領域の配向度の変化
}

\author{
夜京都立大学工学部 岡島三郎・松尾 俊二

\section{THERMAL SHRINKAGE OF POLYACRYLONITRILE FILAMENT AND CHANGE IN THE ORIENTATION DEGREE OF THE AMORPHOUS REGION} \\ By Saburo Okajima and Shunji Matsuo
}

(Faculty of Technology, Tokyo Metropolitan University, Setagaya-Ku, Tokyo, Japan)

A sample of polyacrylonitrile of molecular weight $7.8 \times 10^{4}$ was dissolved in $70 \%$ nitric acid and spun into filament through a glass nozzle of $0.5 \mathrm{~mm} \phi$, using $30 \%$ nitriz acid as a coagulating bath. Three samples of filament were prepared by two-stage stretching : the first stretching was made in water at $60^{\circ} \mathrm{C}$, followed by drying, and the second stretching was made in the boiling saturated solution of ammonium sulphate. The total degrees of stretching were 12.3, 18.5 and 23.1 folds. These samples were shrunk freely by heating in water at $T=60 \sim 170^{\circ} \mathrm{C}$; the degree of shrinkage $S$ amounted to about $20 \%$ at maximum. The change in the orientation degree was traced dichromatically $\left(f_{D}\right)$ and by X-ray method $\left(f_{x}\right)$. The following results were obtained :

(1) Plotting $\log S$ against $1 / T$, a linear relation is found, on which 4 transition points appear at about $94 \sim 96,115,130 \sim 140$ and $160^{\circ} \mathrm{C}$ respectively.

(2) $f_{D^{-}} T$ is also linear with transition points on it; the transition temperatures correspond well with these on the $\log S-1 / T$ line with a few exceptions.

(3) $f_{D}$ drops from 0.80 to 0.15 , while $f_{x}$ from 0.89 to 0.86 after the maximum shrinkage.

Consequently it may be concluded that the thermal shrinkage occurs with disorientation which was predominant in the amorphous region, and it proceeds discontinuosly at the transition points.

(Received July 20, 1965)

\section{1. 緒 需}

高延伸した瀻維を収縮させると絽晶領域の配向度 $f_{x}$ ははとんど低下しないか，あるいは少し上界することす らあることが Wyckoff1るよりポリプロピレンについ て報告されている。このことは取縮時に非晶領域の鎖の 著しい配向度低下を伴ならことを予想させる。しかし近 垻唱えられるように2 折りたたまれ型結晶ができるとし たならば非晶領域の配向度は必ずしも著しくは低下しな くてもよいかむ知れない。これらの問題上別に収縮処理 は，染色性の改善，フィブリル化防此等繊維物性の改善 とも閶連すると考克られ3)，収縮時のとくに非晶領域の 等動を明らかにすることは極好重要である。しかしこ の種の研究はあ新行なわ好ていなようである。

筆者らの一人岡島 ${ }^{4}$ はアクリル䋐維の高温染色時の染 色速度の対数を染色温度の逆数に対してとることにより 染色速度の急变する温度が $T_{\theta}$ 以上にもあること，また 工の時収縮率がその温度で急变すること走知り，それら
の温尿で非晶預域の状態が急に変わることを推定した。 よって本報ではアクリル繊維の高温収縮との関連の下に 非晶領域の配向度变化を調べな結果, 結晶領域の配向度 はほとん亡゙変化がないが，非晶領城の配向度は叹繀率と よく対応して急低下することを知つたので以下に報告す 万o

\section{2. 実 験 法}

\section{$2 \cdot 1$ ポリアクリルニトリル繶維の調製}

旭化成工策株式会社提供のストレートボりマーを尿菜 を少量加えた 70\% 硝酸に溶かして $12 \%$ 溶液とし，眖 泡して $30 \%$ 硝酸溶液中に直径 $0.5 \mathrm{~mm}$ のガラスノズル より静かに押出して等方性のモデル㵶維をつくつた。こ の間ボリマーの扣水分解を防ぐために冷蔵庫中で溶解， 紡弟した。得られた瀻維は水洗し，水中に保存して原糸 とした。その詳細は既報らを参照されたい。ポリマーの 分子量は7.8万といわれている。

$2 \cdot 2$ 染色 
非䐯頜域の配向度老二色性配向度 $f_{D}$ で代表させるた わにコンゴーレッド(CR) で染めた。このためにまず $\mathrm{CR}$ の市販品 (Extra pure) を 50\%エタノール水より 再結晶化に上り精製した。これを 50\%×タノール水に

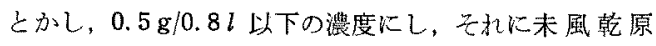

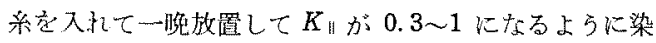
bた。

$f_{D}$ 測定のために用いる対照緎維（I。测定用）および 補正用瀻維 (迷光測定用) は CR で染める時と同様に同

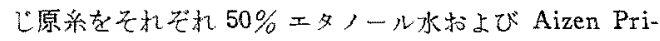
mula Black conc. $550 \% \simeq$ タノール水溶液で, 妈理 または染色した。これらは風乾することなく正体した。

\section{$2 \cdot 3$ 延 伸}

上述の CR 染色瀻維, 対照織維, 補正用緎維恃手動の延伸機に互に接 近して平行に取りつけ, 同時に延伸 した。ます $60^{\circ} \mathrm{C}$ の水中で 4 倍に伸 ばして風乾し，次沙滕飽和酸安溶 液中に入れて $12.3 ， 18.5 ， 23.1$ 倍 に伸ばし，洗浄風乾後に延伸機から はずした。こ礼らの延伸倍率は等方 性染色瀻維を無張力下に風乾したも のを基淮にとつて示した。延伸速度

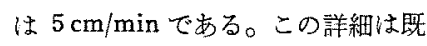
報りを参照されたい。

\section{$3 \cdot 4 f_{D}$ の測定}

試料は $n_{D} 1.52$ のトリクレジル ホスフェート, ジブチルフタレート 混合液に浸して $K_{\|}, K_{\perp}$ を測定し た。刘照瀻維を通過した偏光の強さ をIo, 染色瀻維を通過した偏光の強 さをIとすると

$$
\begin{aligned}
& I / I_{0}=10^{-} \\
& K=\alpha c d
\end{aligned}
$$

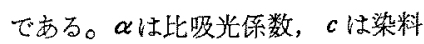
濃度，d注織維の太さである。瀻維 軸に平行および垂淔に振動与る偏光 を使つた時のKをそれぞれ $K_{\|} ， K_{\perp}$ とすると

$$
f_{D}=D / D^{o}=\frac{K_{11}-K_{\perp}}{K_{1}+2 K_{\perp}} / D^{o}
$$

た志し本実駼装置では， $I ， I_{0}$ 中に迷 光が入るので, 補正用瀻維を使つて 補正した。その方法は別報的潐拋 与る。

$D^{\circ}$ は理想的に配向した $f_{D}=1$ の
䋘維のDで，CR 七ルロース系では0.95〜1である。ポ リアクリルニトリルでも 1 とした。

\section{5 収樎}

2.3 の延仰瀻維の長さ $l_{0}(10 \mathrm{~cm}$ 位 $)$ の風乾瀻維を小 型オートクレーブに䋐維か浸るに十分な水とともに入れ， 密閉し，所定温度に保つた油浴中に入れて加熱し，所定 眭間後に取出し，冷却，風乾し，取縮後の長さ $l$ 老测定 し，収縮率 S(\%)を下式により計算した。

$$
S=10^{2}\left(l_{0}-l\right) / l_{0}
$$

小型オートタレーブは $140^{\circ} \mathrm{C}$ 以上はステンレススチー

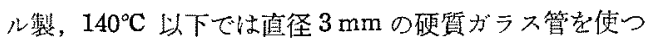
た。收縮時間は $140^{\circ} \mathrm{C}$ 以上は 5 分, $130^{\circ} \mathrm{C}$ 以下は 30 分 とした。予䵊実験によりこれではぼ平衡值に達すること

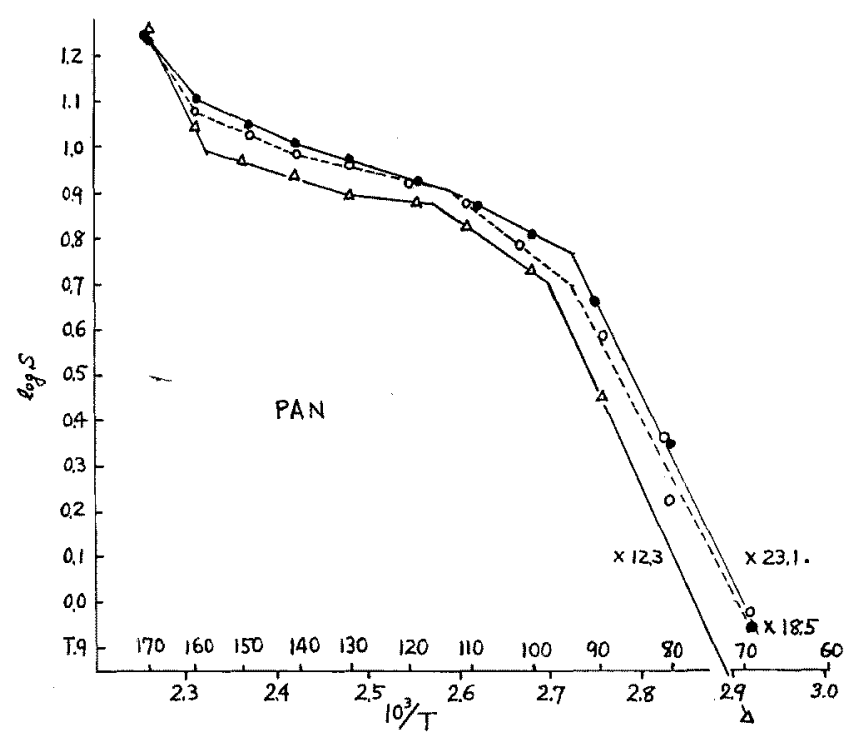

Fig. 1. Thermal shrinkage of polyacrylonitrile filament.

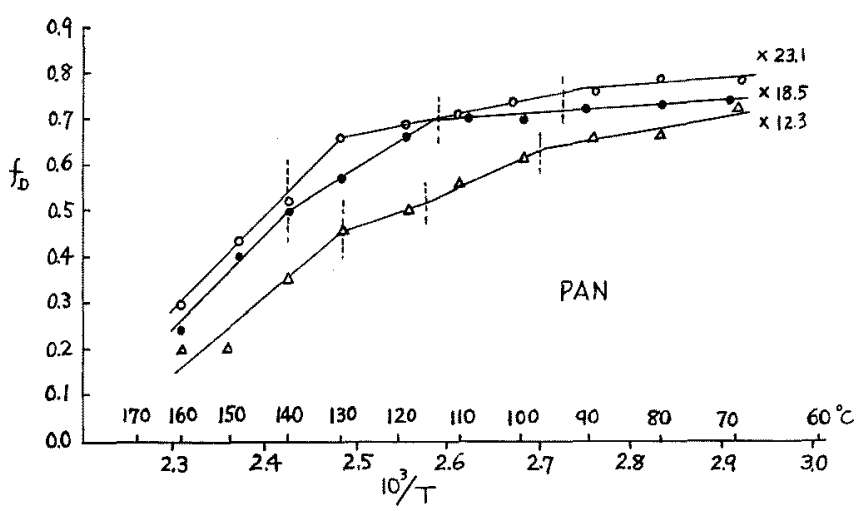

Fig. 2. Changes in the orientation degree of the amorphous region of polyacrylonitrile filament shrink by heating. 
Table I. Relation between $T_{f}$ and $T_{s}$

\begin{tabular}{ccccccccc}
\hline & \multicolumn{4}{c}{$T_{s,}{ }^{\circ} \mathrm{C}$} & & \multicolumn{3}{c}{$T_{f},{ }^{\circ} \mathrm{C}$} \\
\cline { 2 - 7 } $\begin{array}{c}\text { Stretching } \\
\text { degree }\end{array}$ & $(1)$ & $(2)$ & $(3)$ & $(4)$ & & $(1)$ & $(2)$ & $(3)$ \\
12.3 & 97 & 116 & 130 & 157 & & 97 & 116 & 130 \\
18.5 & 94 & 114 & 140 & 160 & & $?$ & 115 & 140 \\
23.1 & 94 & 114 & 140 & 160 & & 91 & $?$ & 130 \\
\hline
\end{tabular}

Table II. Change in $f_{x}$ caused by shrinkage

\begin{tabular}{ccc}
\hline Sample No. & $f_{x}$ & $f_{D}$ \\
1 & 0.893 & 0.80 \\
2 & 0.856 & 0.33 \\
3 & 0.856 & 0.15 \\
\hline
\end{tabular}

を雅かめた。

3. 結果

\section{$3 \cdot 1$ 収縮と非晶領域の配向度变化}

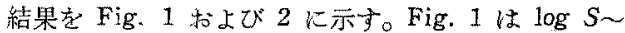

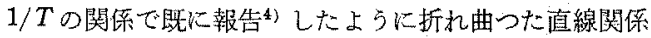

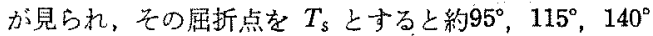
$160^{\circ} \mathrm{C}$ あたりの4コが羿められる。140 $\mathrm{C}$ 付辺の $T_{s}$ は はっきりしない。一定温度で比べる，S江延伸倍部の 大きい蟣維汪ど大きい。

Fig. 2 は Fig. 1 K示した収縮瀻維の $f_{D}$ と収縮鼬度 との関係示したbので，やはり折れ曲つた直楾関係が 見られる。屈折点に相当する温度を $T_{f}$ と主る。四中心

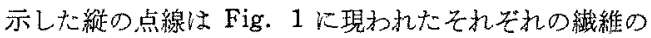
$T_{\text {s }}$ 表わすbのでする。 $f_{D}$ は $160^{\circ} \mathrm{C}$ までしか湘定し ていないのでそれ以下で比べると 12.3 倍延伸瀻維では 共に $T_{f}$ と $T_{s}$ とは一致していることがわかる。18.5 倍 延伸瀻維では最低の $T_{\text {S }}$ に相当する屈曲が極めて軽微で よくわからないが他の 2 点玨一致している。23.1 倍延

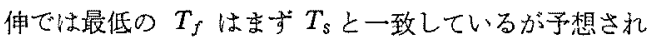
る2点の $T_{s}$ の間に一ユの $T_{f}$ が現加れていて余りょく 一致しているといるない上らである。これらの対応をま とめて Table：I K示したよらに若干の不一致はあるが 大体に执いて $T_{S}$ と $T_{f}$ とは対応寺るようである。 $f_{D}$ は 延伸倍率の大きい程大きい。また $f_{D}$ は $0.7 \sim 0.8$ より $0.2 \sim 0.3$ まで低下し, しかも取縮の変化とよく刘空し ているといえる。次に収維お不喠綂的に起こることが

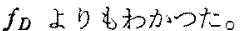

\section{$3 \cdot 2$ 収縮と結晶領域の变化}

原系を $0.5 \mathrm{~g} / 2.4 l$ 执よび $0.5 \mathrm{~g} / 6.4 l$ 濃度の CR の

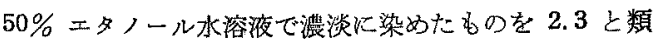
似の方法で 18.5 倍に延伸したもの（No.1）とそれを 収縮させたるの（No，2と3）をつくり，風乾瀻維を平 行に並べて $2 \times 2 \times 1 \mathrm{~mm}$ に成型し，ガイガーフレック スで $2 \theta=16.8^{\circ}$ のデパイシェラー環に治って強度分布を 水め，重た干啮強度 $2 \theta$ 曲線の両裾 $2 \theta=12^{\circ}$ 以下を $21^{\circ}$ 以上飞接す五直線の $2 \theta=16.8^{\circ}$ の高さをつかつて前 記 $2 \theta=16.8^{\circ}$ D強度分布曲線を結晶，非晶領域儿分離し て結晶領域の〈 $\left.\cos ^{2} \varphi\right\rangle$ を求め，配向関数を下式で計算 し，同时に測定した $f_{D}$ とともに示すと

$$
f_{x}=\frac{1}{2}\left(3\left\langle\cos ^{2} \varphi\right\rangle-1\right)
$$

Table II のように $f_{D}$ は 0.80 より 0.15 に急低下する のに $f_{x}$ は 0.89 より 0.86 に低下寸るに過ぎない。こ れにより結晶領域の配向はほとんど変化ないが，収縮时 には非晶領域に著しい配向度低下が起こることがよくわ かる。

な和収縮前の $f_{D}$ と $f_{x}$ とを比べると $f_{D}$ が $0.80, f_{x}$ が0.89 で少しく小さい。CR の $D^{o}$ は0.95〜1ですり， これらの $f_{D}$ の計算では $D^{o}=1$ としたが，い东 $D^{0}=$ 0.95 とすれぱ $f_{D}=0.84$ となり，もっと $f_{z}$ に近つく。 したがって収繀前では結晶非晶両領域の配向度は極めて 近いことがかかる。

本研究をなすにあたりポりアクリルニトリルポリマー

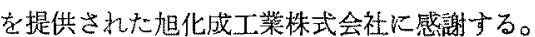

\section{文献}

1) H. W. Wyckoff ; J. Polymer Sci., 62, 83 (1962)

2) W. O. Statton ; J. Polymer Sci., 2 B, 1113 (1964)

D. R. Beresford ; H. Bevan, Polymer, 5, 247 (1964)

A. Peterlin et al.; J. Polymer Sci., 3 B, 151 (1965)

3）岡息三郎；“最近のレオロジーと材料工学”公開 講醧（1964. 6.16。目本化学会講堂）

4) 阔島三郎; 工化，66，1528 (1963)

5) 岡島三郎，久保䗆雄；工化，63，525(1960)

6)岡島三郎; 高分子学会編，高分子実騙学講座，4

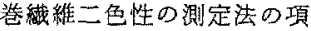
汹島三郎，小林蜻三；染色工業，12，651 (1964) 